\title{
ULTRASTRUCTURE OF THE TRACHEAL EPITHELIUM IN RABBITS (Oryctolagus cuniculus var. edulis) AFTER INTRATRACHEAL ADMINISTRATION OF TWO IODINATED CONTRAST AGENTS
}

\author{
V. KONRÁDOVÁ ${ }^{1}$, S. TƯMA ${ }^{2}$, J. UHLIK ${ }^{1}$, A. ZAJÍCOVÁ ${ }^{1}$, J. ZOCOVA $\AA^{3}$ \\ ${ }^{1}$ Institute of Histology and Embryology, $2^{\text {nd }}$ Medical School, ${ }^{2}$ Clinic of Radiological Techniques, $2^{\text {nd }}$ Medical \\ School and University Hospital Motol and ${ }^{3}$ Department of Applied Mathematics and Computer Science, Faculty \\ of Science, Charles University, Prague
}

Received May 24, 1995

Accepted July 7, 1995

\begin{abstract}
Konrádová V., S. Tůma, J. Uhlík, A. Zajícová, J. Zocová: Ultrastructure of the Tracheal Epithelium in Rabbits (Oryctolagus cuniculus var. edulis) after Intratracheal Administration of Two lodinated Contrast Agents. Acta vet. Brno 1995, 64: 147-155.

The ultrastructure of the tracheal epithelium was studied after intratracheal administration of two contrast agents - iopamidol (Iopamiro) and iohexol (Omnipaque) - used in clinical practice for tracheobronchography. The injury of the tracheal epithelium due to the iopamidol and iohexol administration was classified as mild and moderate, respectively. In both experimental groups bacteria and inspissated mucus were revealed in the area of the impaired ciliary border as morphological signs of the impairment of the self-cleaning ability. The uneven distribution of the contrast media particles were encountered in the airways. In the areas of its highest accumulation the disturbances of the cell membranes and the impairment of the inner structure of the cilia were recorded.
\end{abstract}

Tracheal epithelium, ultrastructure, iodinated contrast media, rabbit

The tracheobronchography has been used as a diagnostic method even in veterinary practice in recent years. In human medicine a new generation of water soluble iodinated nonionic contrast media have been introduced. In our previous study ( $\mathrm{K}$ o $\mathrm{n} \mathrm{r}$ á d o vá et al. 1990b, 1992) we demonstrated that the injection of Hexabrix - a contrast agent with declared low toxicity - into the airways, caused pronounced injury to the tracheal epithelium. Therefore we decided to study the effect of two new contrast media, commonly used in clinical practice for the endoscopic investigation, on the ultrastructure of the airway epithelium. In our experiments we used iopamidol - introduced into the clinical practice under the name IOPAMIRO - and iohexol - used under the name OMNIPAQUE.

\section{Materials and Methods}

In our experiments 9 healthy rabbits (body mass 2,000 - 3,000 g) were used. All animals were of the same origin and were kept under the same conditions. They were divided into 3 groups, each consisting of three animals. The first group of rabbits served as untreated controls. In these animals quantitative evaluation of the ciliary border and the functional state of goblet cells were carried out. These findings were described in detail in our preceding study (K o n rá do vá and Šr a je r 1987).

The remaining rabbits were intubated under thiopental anaesthesia and 3 of them were injected $1 \mathrm{ml}$ of iopamidol (N,N'- bis(2-hydroxy-1-hydroxy-methyl-ethyl)-2,4,6-triiodo-5-lactamido-i sophthalamide) introduced by BRACCO, Industria Chimica of Milan, Italy, under the name IOPAMIRO, into their airways. The remaining three were treated in the same way with $1 \mathrm{ml}$ of iohexol (N,N'- bis(2,3-dihydroxypropyl)-5-[N-(2, 3-dihydroxypropyl)acetamido]-2,4,6-triiodoisophthalamide) produced by NYCOMED a.s. under the name of OMNIPAQUE.

The material for the electron microscopical examination was collected $5 \mathrm{~min}$ after application of the contrast media. The caudal part of the trachea was removed and fragments of its mucous membrane were fixed for $90 \mathrm{~min}$ in $5 \%$ glutaraldehyde in $0.1 \mathrm{M}$ cacodylate buffer at $\mathrm{pH} 7.2$ and then for $60 \mathrm{~min}$ in $2 \% \mathrm{OsO} 4$ in $0.1 \mathrm{M}$ cacodylate buffer at $\mathrm{pH}$ 7.4. Material was dehydrated in graded series of alcohol and embedded in a Durcupan-Epon mixture. Zones 
suitable for ultrathin sectioning were detected in semithin sections, stained with toluidine blue ( $1 \%$ toluidine blue in 9.46\% aqueous $\mathrm{Na}_{2} \mathrm{HPO}_{4}$ solution). Ultrathin sections were prepared with an Ultrotome Nova $\mathrm{LKB}$, contrasted with uranyl acetate and then according to R e y n o l d s (1963). They were examined in JEM $100 \mathrm{C}$ electron microscope.

In all rabbits the ciliary border and the functional state of the goblet cells were evaluated quantitatively. The goblet cells were classified into three groups: 1) mucus-filled ones that did not show signs of secretion, 2) mucusdischarging cells, 3 ) exhausted ones. To estimate quantitatively the degree of injury to the ciliary border the average number of kinocilia per $\mathrm{um}^{2}$ and the proportions of individual types of altered cilia were ascertained. The kinocilia were classified into four groups: 1) intact cilia with $9+2$ inner pattern, 2) slightly damaged pathological cilia with local swellings of the ciliary membrane or with tiny vacuoles situated in their shafts, 3 ) degenerating cilia that were represented by axonemes incorporated into the cytoplasmic blebs on the apical portions of the altered ciliated cells or by isolated axonemes and their fragments situated freely in the area of the ciliary border, 4) malformed cilia with either abnormal arrangement or number of microtubules in their axonemes.

Relative values of the 3 categories of goblet cells and 4 ones of cilia were evaluated by the chi square test of homogeneity in frequency tables. To specify categories causing deflections from the hypothesis of homogeneity adjusted standardized deviations were used. Means of cilia $/ \mu \mathrm{m}^{2}$ were compared by the one-way analysis of variance (AOV) and by a non-parametric analogy of the AOV - Kruskal-Wallis test. The differences between groups were assessed by the Tukey's test for multiple comparison. The Leven's test of homogeneity of variance was also performed.

\section{Results}

\section{Ultrastructure of the tracheal epithelium in control rabbits}

In the group of control rabbits a ciliated pseudostratified columnar epithelium with narrow intercellular spaces was found lining the tracheae. In the apical portions of the epithelium junctional complexes were situated. The epithelium rested on a well developed basal lamina and consisted of ciliated and goblet cells. In the basal area of the epithelium an incomplete row of basal cells and individual cells representing the members of the diffuse neuroendocrine system were found. The differentiating ciliated and goblet cells were observed only exceptionally.

Table 1

Comparison of goblet cells (GC) in the tracheal epithelium of rabbits after intratracheal administration of iodinated contrast media Iopamiro and Omnipaque (relative values)

\begin{tabular}{|c|c|c|c|}
\hline & controls & Iopamiro & Omnipaque \\
\hline mucus-filled GC & $97 \pm 1 \%$ & $57 \pm 6 \%$ & $49 \pm 0 \%$ \\
\hline mucus-discharging & GC $3 \pm 1 \%$ & $\begin{array}{r}27 \pm 7 \% \\
-\quad * * *\end{array}$ & $22 \pm 3 \%$ \\
\hline degenerated GC & 0 & $16 \pm 4 \%$ & $29 \pm 3 \%$ \\
\hline $\begin{array}{l}\text { stimulated GC } \\
\text { (mucus-discharging +degenerated) }\end{array}$ & $3 \pm 1 \%$ & ${ }^{*} 43 \pm L_{* *} 6 \%$ & $* 51 \pm 0 \%$ \\
\hline GC arranged in groups & $6 \pm 3 \%$ & $9 \pm 2 \%$ & $7 \pm 1 \%$ \\
\hline
\end{tabular}

$\mathrm{n}=3$, mean $\pm \mathrm{SD}, * * *$ values differ significantly $(\mathrm{p}<0.001)$ from each other $* *$ values differ significantly $(p<0.01)$ from each other 
The ciliated cells were the most numerous in the epithelium. Individual goblet cells were found among the ciliated ones. Only $6 \pm 3 \%$ of them formed small groups, mostly pairs (Tab.1); $3 \pm 1 \%$ of goblet cells discharged their mucus by means of gradual evacuation of individual apical mucous granules. The mucus-filled goblet cells amounted to $97 \pm 1 \%$.

Table 2

Comparison of the quantitative evaluation of ciliary border of the tracheal epithelium of rabbits after intratracheal administration of iodinated contrast media Iopamiro and Omnipaque (relative values)

\begin{tabular}{|c|c|c|c|}
\hline & controls & Iopamiro & Omnipaque \\
\hline intact kinocilia & $98.8 \pm 0.1 \%$ & ${ }^{88.3 \pm} \pm * * 2.4 \%$ & $94.2 \pm 1.7 \%$ \\
\hline pathological kinocilia & $0.5 \pm 0.2 \%$ & $1.2 \pm 0.2 \%$ & $0.5 \pm 0.2 \%$ \\
\hline degenerating kinocilia & $0.3 \pm 0.1 \%$ & $8.3 \pm 4.1 \%$ & $3.8 \pm 1.2 \%$ \\
\hline malformed kinocilia & $\begin{array}{c}0.4 \pm 0.2 \% \\
L\end{array}$ & 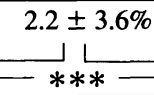 & $\begin{array}{c}1.5 \pm 0.6 \% \\
1\end{array}$ \\
\hline $\begin{array}{l}\text { altered kinocilia } \\
\text { (pathological + } \\
\text { degenerating + malformed) }\end{array}$ & $\begin{array}{c}1.2 \pm 0.1 \% \\
L\end{array}$ & $11.7 \pm 2.4 \%$ & $\begin{array}{c}5.8 \pm 1.4 \% \\
+1 \\
\end{array}$ \\
\hline
\end{tabular}

$\mathrm{n}=3$, mean $\pm \mathrm{SD}, * * *$ values differ significantly $(\mathrm{p}<0.001)$ from each other

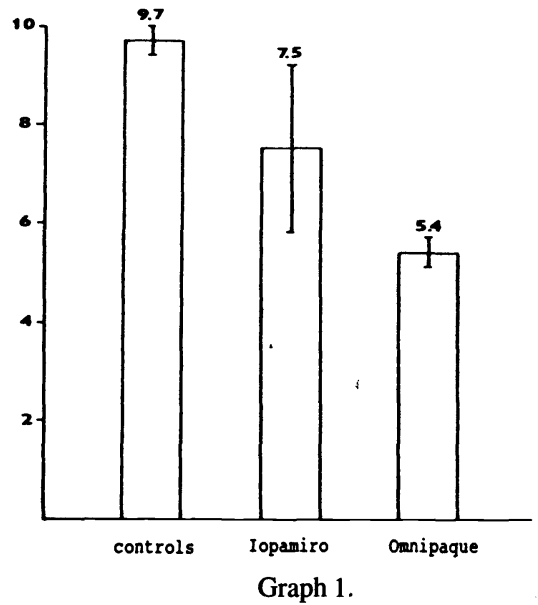

Mean number of cilia per $1 \mu \mathrm{m}^{2}$ of the ciliary border in the trachea of rabbits after intratracheal administration of two iodinated contrast media.

$n=3$, values differ significantly $(P<0.001)$ compared with controls and also from each other. 
On the average $9.7 \pm 0.3$ cilia per $1 \mu \mathrm{m}^{2}$ were found in the area of the regular ciliary border (Graph 1). The cilia were mostly $(98.8 \pm 0.1 \%)$ intact, the total proportion of altered elements was $1.2 \pm 0.1 \%$. The pathological, degenerated and malformed cilia amounted to $0.5 \pm 0.2 \%, 0.3 \pm 0.1 \%$ and $0.4 \pm 0.2 \%$, respectively (Tab. 2 ).

\section{Ultrastructure of the tracheal epithelium 5 minafteriopamidol administration}

Five min after administration of iopamidol into the airways, rabbits' tracheae were lined with an altered pseudostratified ciliated epithelium. The intercellular spaces were mildly dilated in the area above the basal lamina, the apical junctional complexes remained intact.

A few tiny cytoplasmic protrusions were revealed on the apical portions of some ciliated cells (Plate V., Fig.1). Inside these apical blebs a few intact or disintegrating axonemes were usually found. Exceptionally voluminous protrusions with a great number of isolated axonemes were observed.

In the ciliated cells cytoplasm a slight increase in number of secondary lysosomes (Plate V., Fig.2) and the appearance of intracytoplasmic ciliated vacuoles filled with finely fibrogranular matrix, remnants of membranes and tiny vesicles containing electron-dense heterogenous material were encountered. Inside these ciliated vacuoles microvilli and kinocilia protruded. The cilia contained usually axonemes of the $9 \pm 2$ inner pattern, but also elements with atypical number of microtubules were revealed. Among the malformed cilia those with less than 11 microtubular elements prevailed (Plate V., Fig.3). The differentiating ciliated cells with the cytoplasm poor in cytoplasmic organelles with exception of ribosomes, were found only exceptionally in the epithelium.

The goblet cells were mostly scattered as isolated elements among the ciliated ones. Only $9 \pm 2 \%$ of them were arranged in small groups (Tab. 1). In the epithelium the stimulated goblet cells prevailed, they amounted to $43 \pm 6 \%$ (Tab. 1); $27 \pm 7 \%$ of goblet were found in the phase of mucus evacuation. The secretion was mostly discharged by means of gradual evacuation of individual apical mucous granules. The detachment of packets of mucous granules or whole apical mucus-distended portions of the goblet cells were observed only exceptionally, and $16+4 \%$ of goblet cells were completely exhausted. Remnants of their highly electron-dense degenerated cytoplasm were often detected bulging above the neighbouring cells or laying freely in the area of the ciliary border. A few differentiating goblet cells with a few small mucous granules separated by wide cytoplasmic septa were noticed in the epithelium.

On average only $7.5 \pm 1.7 \mathrm{cilia} / \mu \mathrm{m}^{2}$ were counted in the impaired ciliary border (Graph 1 ). The cytoplasmic blebs, remnants of membranes and portions of the electron-dense cytoplasm of the sloughed off degenerated goblet cells impaired the regular arrangement of the cilia above the epithelium. The total proportion of the altered cilia amounted to $11.7 \pm 2.4 \%$. The pathological, degenerating and malformed cilia represented $1.2 \pm 0.2 \%, 8.3 \pm 4.1 \%$ and $2.2 \pm$ $3.6 \%$ respectively (Tab. 2). Numerous bacteria (Plate V., Fig.4), clumps and layers of condensed mucus embedding the free cilia were found in the area of the impaired ciliary border.

In the lumen of the trachea iopamidol appeared as highly electron-dense needle-shaped particles that revealed a tendency to fuse and form tiny aggregates (Plate V., Figs. 4 and 5). These particles were noticed intermingled in the condensed secretion often concentrating at the surface of the layers of inspissated mucus. They struck to the limiting membranes of cilia and bacteria, to the membranes of the apical cytoplasmic blebs and to the portions of the degenerated sloughed off goblet cells. A small amount of the contrast agent was also revealed in the apical portions of the mucus distended goblet cells. The applied contrast agent was not 
uniformly distributed in the lumen of the airways. In the areas of its highest accumulation the electron dense particles penetrated the cilia and disturbed their inner structure (Fig. 5).

Ultrastructure of the trachealepithelium $5 \mathrm{~min}$ afteriohexol administration

Five min after intratracheal application of iohexol an altered pseudostratified ciliated columnar epithelium with narrow intercellular spaces and intact apical junctional complexes was found in the tracheae of the experimental animals.

The process of blebbing was noticed on the apical portions of the ciliated cells. Inside these tiny cytoplasmic protrusions a few axonemes of kinocilia were contained. In the ciliated cells' cytoplasm an increase in small vacuoles, the appearance of voluminous ones containing remnants of partly hydrolysed electron-dense material and swollen mitochondria were revealed (Plate VI., Figs. 6 and 7). Some differentiating ciliated cells were noticed in the epithelium.

Mostly isolated goblet cells were observed in the epithelium, only $7 \pm 1 \%$ of them formed small groups (Tab.1), and $51 \pm 0 \%$ of them were stimulated to discharge mucus, $22 \pm 3 \%$ were encountered in the phase of mucus evacuation. Mucus was mostly discharged from individual apical mucous granules, only exceptionally packets of granules were detached from these cells. The completely exhausted cells represented $29 \pm 3 \%$ of the secretory elements (Tab.1), (Plate VI., Fig. 8).

On average $5.4 \pm 0.3 \mathrm{cilia} / \mu \mathrm{m}^{2}$ were found in the area of the impaired ciliary border (Graph 1). Altered ciliary elements represented $5.8 \pm 1.4 \%$ of all cilia. The proportion of pathological, degenerating and malformed cilia was $0.5 \pm 0.2 \%, 3.8 \pm 1.2 \%$ and $1.5 \pm 0.6 \%$, respectively (Tab. 2). Bacteria and clumps or layers of condensed secretion were observed among the cilia (Plate VI., Fig. 9).

An uneven distribution of the contrast agent was observed in the area of the ciliary border. Iohexol appeared as coarser, larger particles with great tendency to form tiny aggregates (Plate VI., Fig. 10). The particles sometimes concentrated at the surface of the layers of condensed mucus and were also attached to the membranes of the epithelial cells.

\section{Discussion}

The material for our studies of the influence of the intratracheal injection of contrast agents on the ultrastructure of the tracheal epithelium was taken from the caudal part of the trachea out of reach of the catheter to avoid the evaluation of the mechanically damaged mucous membrane. In all our experimental animals altered epithelium was found in the airways, but the apical portions of the epithelial cells showed no signs of mechanical damage. The authors, who studied mechanical injury to the tracheal epithelium caused either by catheter insertion through incision (G o r d o $\mathrm{n}$ and $\mathrm{L}$ a n e 1979; K e e $\mathrm{n}$ a $\mathrm{n}$ et al. 1982, 1983; M a r i n et al. 1979; M c D ow ell et al. 1987) or by intubation (A l t h of $\mathrm{f}$ et al. 1981, L u n d g r e n et al. 1983; N ord in 1982) always found areas where epithelial cells had been mechanically dispatched. In our experiments the epithelium consisted of cells that revealed signs of pathological alteration, but the mechanical damage of the apical portions of these cells was not revealed. The apical cell membranes were all the time intact.

After administration of both contrast agents the apical junctional complexes in the altered tracheal pseudostratified ciliated epithelium remained intact, neither dilatation of the intercellular spaces, nor penetration of free cells through the epithelium were observed.

Alteration of the ciliated cells was noticed after administration of both contrast media. 
A mild apical blebbing associated with destruction of free cilia and an increase in number of intracytoplasmic ciliary vacuoles were noticed in both experimental groups. The appearance of ciliary vacuoles could be taken as a sign of an impairment of the ciliogenesis. More pronounced injury to the ciliated cells was due to the iohexol application. In this experimental group the increase in number of secondary lysosomes was accompanied with appearance of numerous tiny vacuoles, voluminous phagosomes and alteration of the mitochondria in the ciliated cells' cytoplasm.

In the first phase the distribution of the goblet cells in the epithelium was not influenced by the presence of the contrast agents in the airways. All the time the goblet cells were scattered among the ciliated ones, larger groups of goblet cells with the character of intraepithelial mucous glands found in some pathological mucous membranes (Kon rád ová et al. 1985) or in the course of recovery after severe injury to the airways epithelium (K o n rád ov á et al. 1990a) were not noticed in the epithelium.

Due to the treatment with both studied contrast agents the goblet cells were overstimulated. In both experimental groups a significant $(P<0.005)$ increase in number of the stimulated goblet cells was revealed compared with those in control rabbits. Also the mechanism of secretion was accelerated. Though mucus was still mostly discharged gradually from the individual apical mucous granules, the detachment of whole packets of granules was observed. The percentage of mucus-discharging and completely exhausted goblet cells differed significantly compared with controls and also with each other. The higher degree of goblet cells stimulation due to the iohexol administration was reflected not only by significantly higher percentage of stimulated goblet cells but also of the completely exhausted ones.

In both experimental groups the decrease in the average number of cilia/ $\mu \mathrm{m}^{2}$ was accompanied by an increase in number of the altered elements in the impaired ciliary border. The injury to the ciliary border was significantly more serious due to the iohexol application. The average number of cilia $/ \mu \mathrm{m}^{2}$ after treatment with iohexol differed significantly $(\mathrm{P}<0.005)$ compared both with controls and with that after iopamidol application. The lower percentage of the altered cilia after iohexol administration was a result of higher degree of the ciliated cells alteration connected with loss of kinocilia.

In all experimental animals after injection of the contrast media into their airways bacteria and inspissated mucus were found in the area of the ciliary border. In agreement with our previous studies (K o n rá d o vá and Š r a j e r 1987) and also with other authors who have studied the relation of the cilia to the layer of mucus in the airways ( $\mathrm{H} \mathrm{u} \mathrm{l} \mathrm{b} \mathrm{e} \mathrm{rt}$ et al. 1982; $\mathrm{S} \mathrm{t} \mathrm{u} \mathrm{r} \mathrm{g} \mathrm{e} \mathrm{s} \mathrm{s}$ 1977; Y o n e d a 1976), we regard the condensed secretion with numerous entrapped bacteria that embed the free kinocilia as morphological signs of local mucus flow disturbances.

In the lumen of the airways the contrast agents appeared as highly electron-dense particles that revealed the tendency to fuse. The differences in the shape of the contrast agent particles could be demonstrated. Iopamidol appeared as tiny needle-shaped particles, the iohexol particles were coarser, larger, with greater tendency to fuse.

The distribution and the amount of the contrast agent was about the same in both experimental groups. In the areas of its highest accumulation the disturbances of the cell membranes connected with the impairment of the inner structure of the cilia were encountered.

Based on our previous findings a classification of the injury to the airways' epithelium was proposed (K o n rá d o vá 1991). The degree of the damage of this epithelium was classified as mild, moderate or severe. The differences were found not only in the degree of pathological alteration of the cells forming the epithelium, but also in the degree of the impairment of the vital self-cleaning ability (Tab. 3). 
Table 3

Quantitative evaluation of the degree of injury to the tracheal epithelium

\begin{tabular}{|l|c|c|c|}
\hline \multirow{2}{*}{} & \multicolumn{3}{|c|}{ Injury to the tracheal epithelium } \\
\cline { 2 - 4 } & mild & moderate & severe \\
\hline stimulated GC & $<50 \%$ & $50-90 \%$ & $>90 \%$ \\
\hline \multicolumn{1}{c|}{ discharging GC } & $>1$ & $0.1-1$ & $<0.1$ \\
\hline $\begin{array}{l}\text { mean number of } \\
\text { cilia/um }{ }^{2}\end{array}$ & $>7$ & $3-7$ & $<3$ \\
\hline $\begin{array}{l}\text { altered cilia } \\
\text { ratio GC }\end{array}$ & $<10 \%$ & $<10 \%$ & $>10 \%$ \\
\hline $\begin{array}{l}\text { signs of impairment } \\
\text { ability }\end{array}$ & 0 & + & ++ \\
\hline
\end{tabular}

\begin{tabular}{|l|c|c|}
\hline & Iopamiro & Omnipaque \\
\hline stimulated GC & $43 \%$ & $51 \%$ \\
\hline$\frac{27 \%}{\text { discharging GC }}$ & $\frac{22 \%}{16 \%}=1.7$ & $\frac{29 \%}{\text { degenerated GC }}$ \\
\hline $\begin{array}{l}\text { mean number of } \\
\text { cilia/um }\end{array}$ & 7.5 & 5.4 \\
\hline $\begin{array}{l}\text { altered cilia } \\
\begin{array}{l}\text { signs of impairment } \\
\text { of self-cleaning } \\
\text { ability }\end{array}\end{array}$ & $11.7 \%$ & $5.8 \%$ \\
\hline
\end{tabular}

$\mathrm{GC}=$ goblet cells

According to this classification the damage of the tracheal epithelium due to the iopamidol administration was estimated as mild (Tab. 3). The stimulated goblet cells amounted to less than $50 \%$ of all secretory elements in the epithelium, the completely exhausted, degenerated goblet cells represented the smallest group of the secretory elements in the epithelium. The average number of cilia/ $\mu \mathrm{m}^{2}$ was higher than 7 . The altered cilia represented slightly more than $10 \%$ of all remaining kinocilia, but the proportion of pathological and degenerating cilia, which most precisely reflected the immediate reaction of the ciliated cells to the treatment with foreign agents, amounted only to $9.5 \%$. Due to the iopamidol administration morphological signs of local mucus-flow impairment were recorded in the airways. We demonstrated, that the morphological signs of the impairment of the self-cleaning ability did 
not usually appear in the slightly damaged epithelium (K o n r á d o vá 1991). We therefore arrived at the conclusion that iopamidol probably also displayed a rather pronounced ciliostatic effect.

The injury to the tracheal epithelium caused by the treatment with iohexol could be classified as moderately severe (Tab. 3). The percentage of the stimulated goblet cells was higher than $50 \%$, the exhausted goblet cells were more numerous than the mucus-discharging ones. The average number of cilia/ $\mu \mathrm{m}^{2}$ was less than 7 . The altered ciliary elements did not amount to the $10 \%$ level. According to our expectation the signs of the impairment of the self-cleaning ability were encountered in this injured epithelium.

\section{Ultrastruktura epitelu trachey králíků (Oryctolagus cuniculus var. edulis) po intratracheální aplikaci dvou jodovaných kontrastních látek}

Po intratracheální aplikaci dvou jodovaných kontrastních látek - iopamidolu (Iopamiro) a iohexolu (Omnipaque) - užívaných v klinické praxi pro tracheobronchografii byla studována ultrastruktura epitelu trachey králíkủ. Poškození epitelu bylo hodnoceno jako lehké po podání iopamidolu a středně těžké po aplikaci iohexolu. U obou experimentálních skupin byly nalezeny $\mathrm{v}$ oblasti poškozeného řasinkového lemu četné bakterie a shluky nebo vrstvy zahuštěného hlenu jako morfologické známky narušení samočistící schopnosti epitelu. V dýchacích cestách se vyskytovaly nerovnoměrně rozmístěné partikule kontrastních látek. $\mathrm{V}$ místech jejich největši akumulace došlo $\mathrm{k}$ porušení buněčných membrán a $\mathrm{k}$ poškození vnitřní struktury řasinek.

\section{References}

ALTHOFF J., RICHTER-REICHHELM H. B., GREEN U., KRACKE D. 1981: Scanning electron microscopical investigation on the respiratory epithelium of the syrian golden hamster III. Zbl. Bakt. Hyg. I Abt. Orig. B 174:249-259

GORDON R. E., LANE B. P. 1976: Regeneration of rat tracheal epithelium after mechanical injury. Am. Rev. Resp. Dis. 113:799-807

HULBERT W. C., FORSTER B. B., LAIRD W., PIHL C. E., WALKER D. C. 1982: An improved method for fixation of the respiratory epithelial surface with the mucous and surfactant layers. Lab. Invest. 47:354-363

KEENAN K. P., COMBS J. W., McDOWELL E. M. 1982: Regeneration of hamster tracheal epithelium after mechanical injury I-III. Virchows Arch. B 41:193-252.

KEENAN K. P., WILSON T. S., McDOWELL E. M. 1983: Regeneration of hamster tracheal epithelium after mechanical injury. Virchows Arch. B 43:213-240

KONRÁDOVÁ V . 1991: Quantitative evaluation of the degree of damage to tracheal epithelium. Funct. Dev. Morph. 1:47-50

KONRÁDOVÁ V., ŠRAJER J. 1987: Quantitative evaluation of the ciliary border of the epithelium of the rabbit trachea and the human primary bronchus. Folia Morphol. 35:67-74

KONRÁDOVÁ V., ČOPOVÁ M., SUKOVÁ B., HOUŠTĖK J. 1985: Ultrastructure of the bronchial epithelium in three children with asthma. Ped. Pneumology 1:182-187

KONRÁDOVÁ V., KANTA J., ŚULOVÁ J. 1990: Regeneration of changes produced in rabbit tracheal epithelium by saline lavage of the airways. Folia Morphol. 38:28-37

KONRÁDOVÁ V., TƯMA S., KANTA J. 1990: The effect of Hexabrix tracheobronchography on the ultrastructure of the airway epithelium. Pediatr. Radiol. 20:440-443

KONRÁDOVÁ V., TƯMA S., KANTA J., ŚULOVÁ J. 1992: Ultrastructure of rabbit tracheal epithelium after the administration of Hexabrix - a hexaiodated contrast agent for tracheobronchography. Funct. Dev. Morph. 2:3337

LUNDGREN R., HORSTEDT P., WINBLAND B. 1983: Respiratory damage by flexible fibroptic bronchoscopy in pigs. Eur.J.Respir. Dis. 64: 24-32.

MARIN M. L., GORDON R. E., LANE B. P. 1979: Development of tight junctions in rat tracheal epithelium during early hours after mechanical injury. Am. Rev. Resp. Dis. 119:101-106

McDOWELL E. M., BEN T., NEWKIRK C., CHANG S., DeLUCA L. M. 1987: Differentiation of tracheal mucociliary epithelium in primary cell culture recapitulates normal fetal development and regeneration following injury in hamsters. Am. J. Pathol. 129: 511-522 
NORDIN U. 1982: The regeneration after cuff-induced tracheal injury. Acta Otolaryngol. 94:541-555

REYNOLDS E. S. 1963: The use of lead citrate at high pH as an electronopaque stain in electron microscopy. J.

Cell. Biol. 17: 203-212

STURGESS J. M. 1977: The mucous lining of major bronchi in the rabbits lung. Am. Rev. Resp. Dis. 115:819-827

YONEDA K. 1976: Mucous blanket of rat bronchus. Am. Rev. Resp. Dis. 114:837-842

Address for correspondence

Doc. MUDr. Václava Konrádová DrSc.

Institute of Histology and Embryology

$2^{\text {nd }}$ Medical School, Charles University

$\mathrm{V}$ úvalu 84

15018 Praha 5

Czech Republic 
Plate V.

Konrádová V. et. al.: Ultrastructure... pp. 147-155
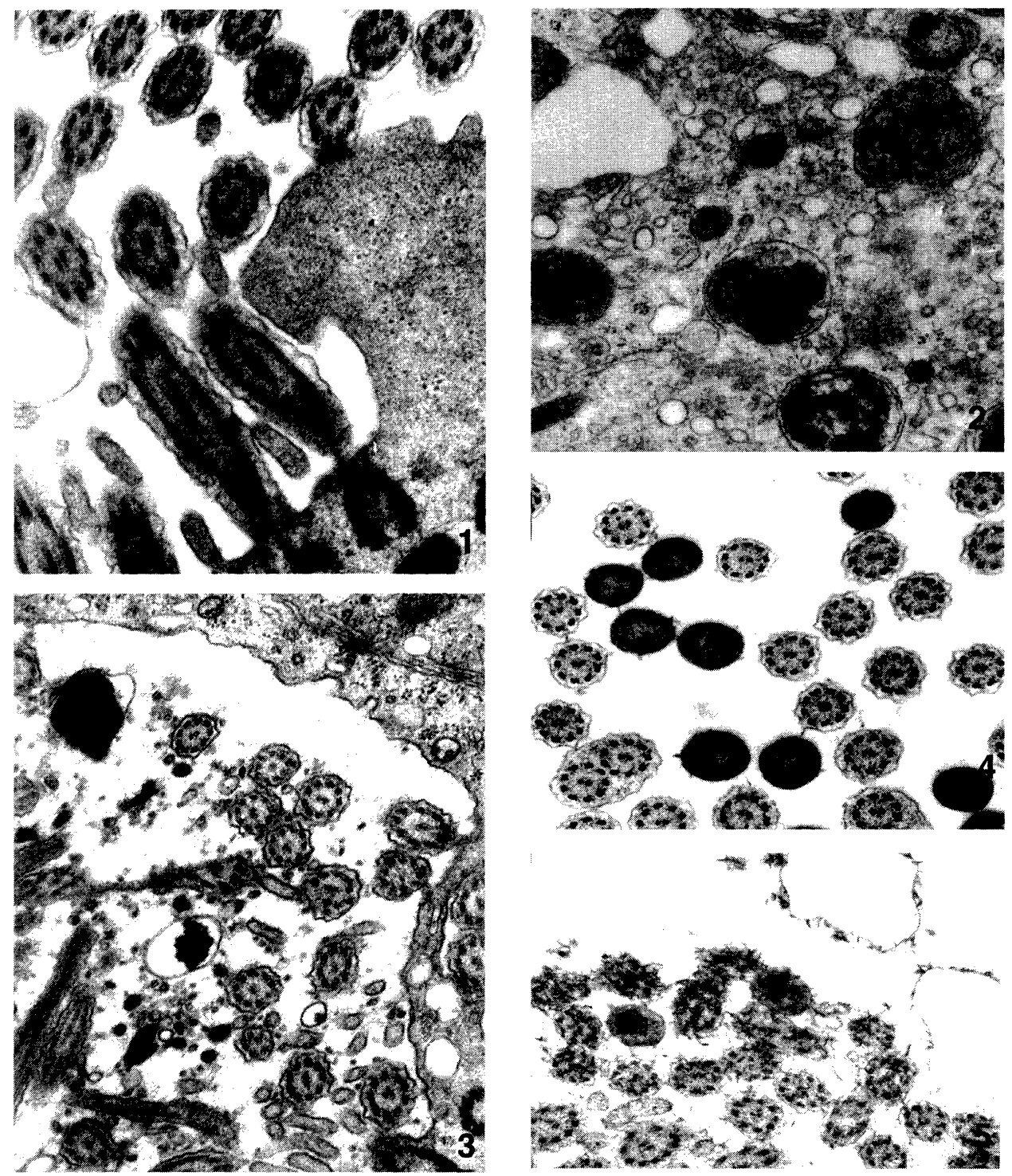

Fig 1. Small cytoplasmic protrusion on the apical portion of the ciliated cell. Rabbit - tracheal epithelium - 5 min. after intratracheal administration of iopamidol - x 50,000

Fig. 2. Small secondary lysosomes in the cytoplasm of the ciliated cell. Rabbit - tracheal epithelium - 5 min. after intratracheal administration of iopamidol - $x$ 37,500

Fig 3. Intracytoplasmic ciliary vacuole in the cytoplasm of the ciliated cell. Rabbit - tracheal epithelium - 5 min. after intratracheal administration of iopamidol - $x$ 37,500

Fig. 4. Numerous bacteria in the slightly altered ciliary border. Needle-shaped electron-dense particles of iopamidol are attached to the limiting membranes of kinocilia and bacteria.

Rabbit - tracheal epithelium - 5 min. after intratracheal administration of iopamidol - $x$ 50,000

Fig. 5. Area of the altered ciliary border with high accumulation of the iopamidol particles. Rabbit - tracheal epithelium - 5 min. after intratracheal adminsitration of iopamidol - $x$ 62,500 

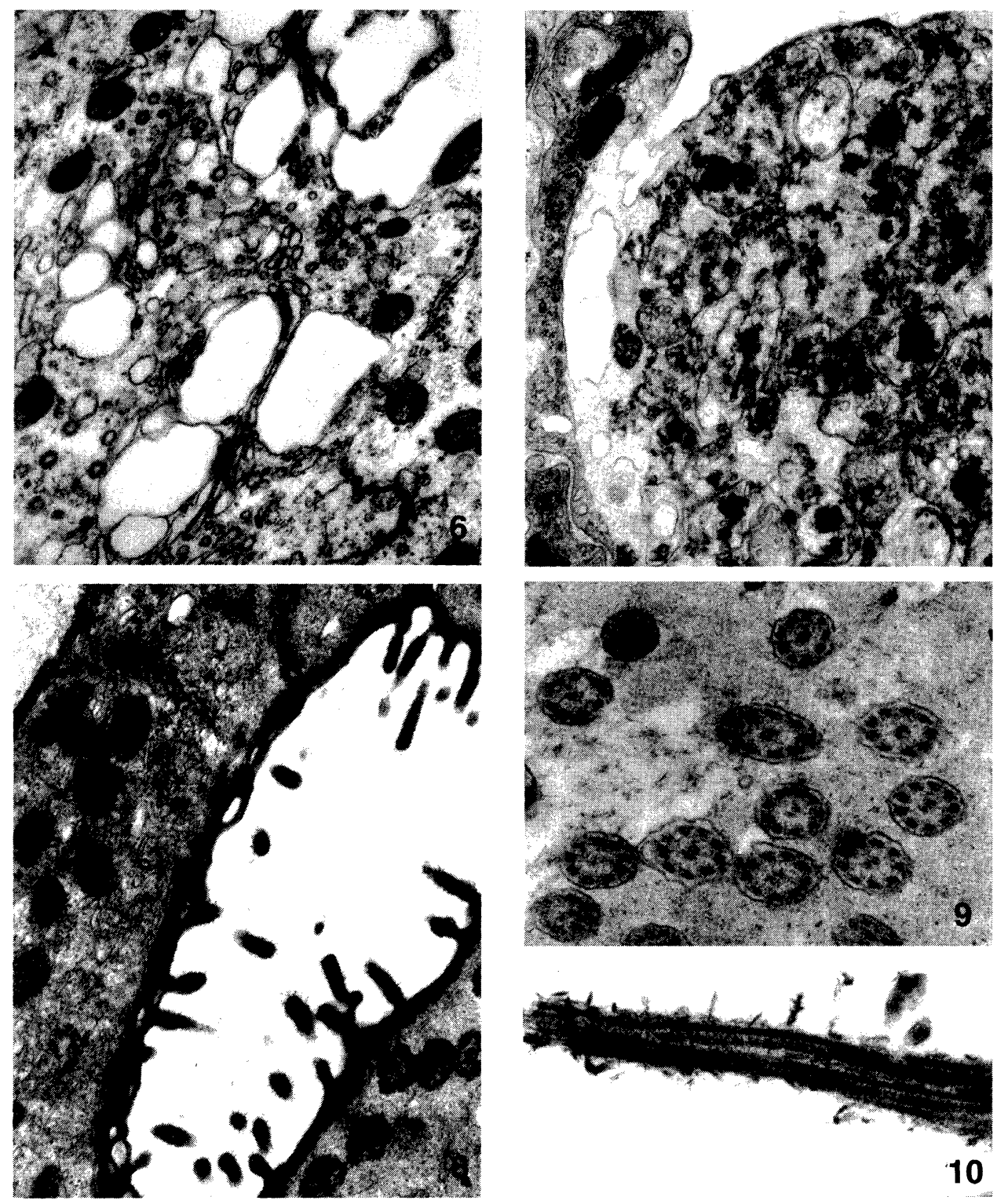

10

Fig. 6. Numerous larger vacuoles in the cytoplasm of altered ciliated cell. Rabbit - tracheal epithelium - 5 min. after intratracheal administration of iohexol - x 37,500

Fig. 7. Voluminous vacuole with remnants of partly hydrolysed electron-dense material in the cytoplasm of altered ciliated cell. Rabbit - tracheal epithelium - 5 min. after intratracheal administration of iohexol - $x$ 25,000

Fig. 8. Rim of the degenerated cytoplasm of the exhausted goblet cell lining the cavity left after rapid mucus evacuation. Rabbit - tracheal epithelium - 5 min. after intratracheal administration of iohexol - x 37,500

Fig. 9. Layer of condensed secretion embedding free cilia. Rabbit - tracheal epithelium - 5 min. after intratracheal administration of iohexol - $x$ 50,000

Fig. 10. Iohexol particles in the area of the altered ciliary border. Rabbit - tracheal epithelium - 5 min. after intratracheal administration of iohexol - $x$ 50,000 